\title{
OS NÃO RECUPERÁVEIS-PSICOPATAS E O SISTEMA JURÍDICO PÁTRIO
}

\section{EMANUELLE CAROLLINE DA SILVA LIMA}

Acadêmica do curso de Direito - Faculdade do Litoral Paranaense - ISEPE Guaratuba. Guaratuba - PR . E-mail: manu.tabelionatoguaratuba@gmail.com

\section{LUCIANO RAITER}

Professor Orientador - Faculdade do Litoral Paranaense - ISEPE Guaratuba. Guaratuba - PR. E-mail: direito@isepe.edu.br

\section{RESUMO}

No sistema processual penal brasileiro todos os acusados de crimes contra à vida respondem pela justiça comum. Mesmo que durante o processo seja constatado que o indivíduo é portador de psicopatia grave, se condenado, estará sujeito à Lei de Execuções Penais assim como qualquer outro indivíduo que seja considerado 'mentalmente saudável'. De forma majoritária pela doutrina e jurisprudência, o psicopata é considerado semi-imputável, sendo a ele aplicado o parágrafo único do art. 26 do Código Penal. Quando não há um laudo técnico do perito, que comprove a psicopatia, o sujeito responde como semi-imputável, ou seja, cumprirá a pena em presídio comum, tendo em vista que no Brasil ainda não há um presídio especial para portadores de psicopatia. Conforme estudos de diversos artigos já publicados, portadores de psicopatia grave, que cometeram crimes contra vida, tornarão a reincidir se colocados novamente no convívio em sociedade, a relevância desta pesquisa, é a de verificar a possibilidade de não se permitir a progressão de pena para esses indivíduos, conforme exemplo da decisão do STF que mantém em regime fechado o alcunhado "Champinha" por entender que este 
Personalidade Acadêmica Homenageada:

Raymundo Juliano Feitosa (Universidade Federal do Rio Grande do Norte - UFRN)

não possui condições de conviver em sociedade. Pode-se dizer que, além deste há inúmeros casos de apenados que não foram diagnosticados corretamente e são portadores de psicopatia grave, estando eles em regime de progressão de pena em condições de vir a estar em liberdade. Considerando este contexto, elegeu-se a seguinte problemática: Com base no ordenamento jurídico pátrio, é possível manter afastados do convívio em sociedade os indivíduos diagnosticados com psicopatias graves e que cometeram crimes contra a vida? Para responder esta pergunta, optou-se pela pesquisa bibliográfica, com base principalmente na lei, doutrina, jurisprudência e artigos científicos pertinentes, e em estudo de caso. Preliminarmente é possível afirmar que é possível manter estes indivíduos fora do convívio em sociedade, utilizando-se o mesmo critério no qual o STF entendeu que o alcunhado "Champinha" não reunia condições mínimas, decisão esta amparada em laudo especializado.

PALAVRAS-CHAVE: Lei de Execuções Penais; Apenado Psicopata; Regime de Progressão.

\section{REFERÊNCIAS}

BANHA, Nathalia Cristina Soto. A resposta do estado aos crimes cometidos por psicopatas. Disponível em:< http://www.ambitojuridico.com.br/site/index.php?n link=revista artigos leitura\&artigo id=5321 > Acesso em: 22/05/2018

CAVALHEIRO, Talissa Alves. A atual punibilidade aplicada ao psicopata homicida na política criminal brasileira. Disponível em: $<$ https://jus.com.br/artigos/55041/a-atual-punibilidade-aplicada-ao-psicopatahomicida-na-politica-criminal-brasileira>. Acesso em: 15/05/2018

TOMAZ, Kleber. STF decide manter Champinha internado em unidade de saúde de SP. Disponível em: <http://g1.globo.com/sao-paulo/noticia/2015/03/stf-decidemanter-champinha-internado-em-unidade-de-saude-de-sp.html>.

Acesso em:20/07/2017. 